www.jmscr.igmpublication.org Impact Factor 5.244

Index Copernicus Value: 5.88 ISSN (e)-2347-176x ISSN (p) 2455-0450 crossref DOI:_http://dx.doi.org/10.18535/jmscr/v4i5.38

Journal Of Medical Science And Clinical Research

\title{
In-Vitro Screening of Phyllanthus Amarus and Eclipta Alba Against Leptospira Autumnalis
}

\author{
Authors \\ Arthi Mohan ${ }^{1}$, Saradhai Pandurangan ${ }^{2}$, Saravanan Ramalingam ${ }^{3}$ \\ ${ }^{1}$ PG \& Research Department of Microbiology, DKM college for Women, Vellore \\ Email:arthimhn88@gmail.com \\ ${ }^{2}$ PG \& Research Department of Microbiology, Presidency College, Chennai \\ Email: psaradhai1978@gmail.com \\ ${ }^{3}$ Biomedical Engineering and Research Foundation, Salem \\ Email:saravana69@gmail.com. \\ Corresponding Author \\ Saradhai Pandurangan \\ PG \& Research Department of Microbiology, Presidency college, Chennai. \\ Email: psaradhai1978@gmail.com, Mobile: 8438996429
}

\begin{abstract}
Background and Study Aims: Multi-drug resistance is one of the major public health problems especially in developing countries where relatively easy availability and higher consumption of medicines have lead to disproportionately higher incidence of inappropriate use of antibiotics and greater levels of resistance compared to developed countries. Leptospirosis is the most wide spread zoonoses in the world and recognized as an important public health problem.

Aim and Methods: To extract and identify some phytochemicals from the commonly available and widely studied Indian medicinal plants (Phyllanthus amarus and Eclipta alba) with anti-bacterial, hepatoprotective and renoprotective properties and also to conduct an anti-leptospiral susceptibility study on MIC of a most common Leptospira interrogans serovar autumnalis following the standard TDT.

Results: The present study revealed the presence of tannins, alkaloids, saponins, flavonoids, terpenes and anthraquinones in the leaves of these plants extracts thereby exhibiting anti-leptospiral activity. The drug dose concentration the extracts of $P$. amarus was found to be having a better active principle $(160 \mu \mathrm{g} / \mathrm{ml}) \mathrm{than}$ the extracts of E. alba $(320 \mu \mathrm{g} / \mathrm{ml})$.

Keywords: Leptospira autumnalis, P. amarus, E. alba, Tube dilution technique.

Abbrevations: TDT= Tube Dilution Technique, MIC= Minimum Inhibitory Concentration.
\end{abstract}

\section{Introduction}

Leptospirosis a contemporary infectious disease also known as Weil's syndrome is an emerging and re-emerging life threatening zooanthroponotic disease which affects internal organs producing multiple organ dysfunctions [MOD] to multiple organ failure [MOF] (Isa et al., 2014). Leptospirosis is a notifiable disease in India for 
the past three decades no accurate disease incidence figures are available. Leptospira has hit virtually all parts of urban, semiurban, semirural and rural India (Parasuraman et al., 2014). It is a serious contagious disease commonly transmitted by not only the urine of rats but also it spreads through flood waters, garbage, wet ground and contaminated plants (Calvo-Cano et al., 2014). Emergence of multiple drug resistant strains of microbial pathogens including Leptospira occurs due to indiscriminate use of antibiotics (Kumar, et al., 2013). Due to allergic problems and side effects produced by chemotheraphy today, people are showing greater interest towards alternate therapeutic methods especially of herbal medicines (Chakraborty et al., 2010). It is safer than synthetic medicines because of the presence of several anti-microbial metabolites like alkaloids, anthroquinoes, tannins, flavonoids, glycosides, essential oils, saponins, phytosterols, amides, etc in the plant extract which target the biochemical pathways of bacteria only and not on human physiology (Maity et al., 2013). However, detailed studies pertaining to the active principles of herbal drugs are very limited. Herbal extracts' of hepatoprotective and renoprotective phytochemicals from important medicinal plants are need of this hour. In the present study Phyllanthus amarus and Eclipta alba were screened for their anti-leptospiral activity especially on Leptospira autumnalis to overcome the side effects produced by synthetic drugs.

\section{Materials and methods}

\section{Collection of plant material}

The Fresh whole plant of Phyllanthus amarus were received from ABS medicinal plant research center, Karippatti, Salem Tamilnadu, India during the month of December 2013. Fresh plant leaves were washed with distilled water, air dried at room temperature ground into powder and stored until further use.

\section{Preparation of aqueous extract}

Ten grams of air-dried powder was added to distilled water and boiled on slow heat for $2 \mathrm{~h}$ (Sadiaque, et al., 1989). It was then filtered through8 layers of muslin cloth and centrifuged at $5000 \mathrm{~g}$ for $10 \mathrm{~min}$. The supernatant was collected and the same procedure was repeated twice. After $6 \mathrm{~h}$, the supernatant collected at an interval of every $2 \mathrm{~h}$, was pooled together and concentrated to make the final volume one-fourth of the original volume (Parekh, et al., 2005).

\section{Preliminary qualitative phytochemical analysis}

The preliminary qualitative phytochemical analysis of P. amarus and E. alba was performed to screen for the presence of bio-active components in the selected plant leaves (Evans, 1989; Sofowora, 1993).

\section{Anti-leptospiral susceptibility testing (Tube Dilution Technique)}

The efficacy of Phyllanthus amarus extract (PAE) and Eclipta alba extract (EAE) against Leptospira interrogans serogroup autumnalis was investigated by Minimum Inhibitory Concentration (MIC) study of the extracts following the standard method of Tube Dilution Technique (TDT) (Oie et al., 1983; Mathew, 2001). $1 \mathrm{ml}$ of various concentrations of plant extracts ranging from 5, $10,20,40,80,160,320$ and $640 \mu \mathrm{g} / \mathrm{ml}$ was added in the Ellinghausen, McCullough, Johnson and Harris (EMJH) liquid medium. Sterility checking of the medium was done by placing it in the room temperature for $48 \mathrm{~h}$, the Leptospira autumnalis were inoculated with syringe filter. The tubes were incubated at room temperature for 8 days. The inhibition patterns in different concentrations were observed under darkfield microscope by placing a loopful of suspension on the clear glass slide and observed under different magnifications of the darkfield microscope. The inhibition profile of the extracts were tabulated and compared with control. Experiments were carried out in duplicates and repeated for three times. The 
results of both the extracts were described to improve the therapeutic values of the leptospirosis by the predominant serogroup. The antimicrobial standardization of the spirochaetal member was studied in Tube dilution technique and screened under darkfield microscope and the results were impregnated as percentages.

\section{Results}

\section{(a)Preliminary qualitative screening of PAE and EAE}

The preliminary screening tests may be useful in detection of bioactive principles and subsequently may lead to drug discovery and development. Several workers use different solvents a system for the extraction of bioactive compounds in the current study water was utilized as a solvent system, traditional healers use primarily water since it is a safe solvent compared to other solvents for preparing ayurvedic formulations. The phytochemical analysis of the current study revealed the presence of tannins, alkaloids, saponins, flavanoids, terpenes and anthraquinones in the leaves of P. amarus and E. alba.

\section{(b) Anti-leptospiral susceptibility testing (Tube Dilution Technique)}

The tube dilution technique was followed for the conduction of MIC of chosen medicinal plant extracts. The aqueous extracts of both the selected plants showed satisfactory leptospiral inhibitory property. The MIC value was observed from $5 \mu \mathrm{g} / \mathrm{ml}$ to $640 \mu \mathrm{g} / \mathrm{ml}$; the maximum inhibition $(100 \%)$ for PAE was found to be $\geq 160 \mu \mathrm{g} / \mathrm{ml}$. For EAE the complete inhibition was at $\geq 320 \mu \mathrm{g} / \mathrm{ml}$. Thus the MIC effect of PAE extract was found to be comparatively superior to the extracts of E. alba. Standard antibiotic doxycyline (Control) exhibited the MIC at $200 \mu \mathrm{g} / \mathrm{ml}$. The results are given in detail.

\section{MIC of PAE}

P. amarus extract (PAE) of known quantities were dissolved in each $1 \mathrm{ml}$ of sterile phosphate buffered saline (PBS) $7.2 \mathrm{pH}$ and used for the anti-leptospiral activities. A negative control of plain sterile saline was used simultaneously along with the test vials. Starting from $5 \mu \mathrm{g} / \mathrm{ml}$ double fold concentration of up to $640 \mu \mathrm{g} / \mathrm{ml}$ were prepared and treated with approximately $2 \times 10^{4} /$ $\mathrm{ml}$ of Leptospira. The results were observed on $1^{\text {st }}, 2^{\text {nd }}, 4^{\text {th }}, 6^{\text {th }}, 8^{\text {th }}$ and $10^{\text {th }}$ day of the PI (Post inoculation). On $1^{\text {st }}$ and $2^{\text {nd }}$ day of observation PAE exhibited least inhibition (33\% and 44\%) even at $620 \mu \mathrm{g} / \mathrm{ml}$ concentration.

\section{(i) $4^{\text {th }}$ day observation}

Interesting results were observed only from the 40 $\mu \mathrm{g} / \mathrm{ml}$ concentration with $54 \%$ of reduction for the pathogen's growth inhibition potentiality. Up to $20 \mu \mathrm{g} / \mathrm{ml}$ concentration the PAE was giving up to $39 \%$ of anti-leptospiral inhibition only. In the 80 $\mu \mathrm{g} / \mathrm{ml}$ concentration the reduction was $54 \%$ but in the next higher concentration $(160 \mu \mathrm{g} / \mathrm{ml})$ the inhibition was to a tune of $61 \%$. Interestingly in the next higher concentration $(320 \mu \mathrm{g} / \mathrm{ml}$ and 640 $\mu \mathrm{g} / \mathrm{ml}$ ) $71 \%$ and $85 \%$ inhibition of the Leptospira was able to be observed (Figure: 1).

MIC of PAE against $L$. autumnalis

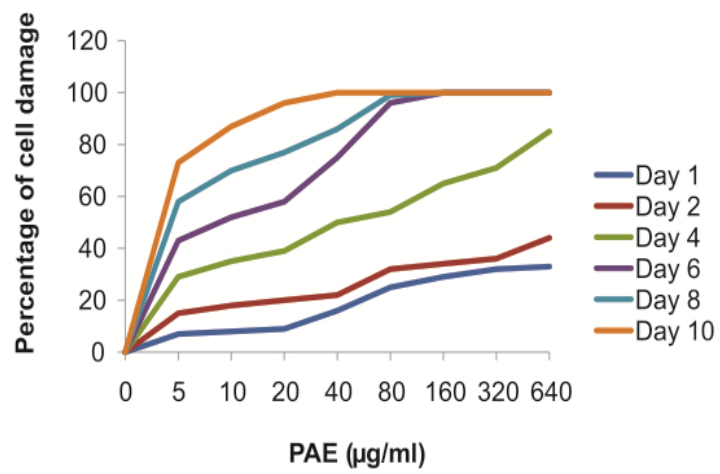

(ii) $6^{\text {th }}$ day observation

During the $6^{\text {th }}$ day observations for up to $80 \mu \mathrm{g} / \mathrm{ml}$ extract concentrations, the L. autumnalis growth was observed to be declining sharply. On the $6^{\text {th }}$ day approximately $43 \%$ of decline in leptospiral density was noted when compared with that of the negative control. The Leptospira growth reduction of $58 \%$ in $20 \mu \mathrm{g} / \mathrm{ml}$ with the P. amarus treatment was noted. Interestingly in $80 \mu \mathrm{g} / \mathrm{ml}$ around $96 \%$ of reduction was noted. From the next 
concentration of $160 \mu \mathrm{g} / \mathrm{ml}$, no live Leptospira (100\% inhibition) was observed.

\section{(ii) $8^{\text {th }}$ day observation}

On the $8^{\text {th }}$ day observation a sharp decline in growth of the Leptospira was noted up to a concentration of $80 \mu \mathrm{g} / \mathrm{ml}$ extract treatment. On this day $5 \mu \mathrm{g} / \mathrm{ml}$ treatment, approximately $58 \%$ growth reduction was noted when compared with that of the negative control. While doubling the concentration $(10 \mu \mathrm{g} / \mathrm{ml})$ a gradual increase in inhibition of $70 \%$ was noted. Similarly for the next concentration $(20 \mu \mathrm{g} / \mathrm{ml})$ the inhibition in growth was noted as $77 \%$. But with the same extract at $80 \mu \mathrm{g} / \mathrm{ml}$ a reduction of $99 \%$ was noted. While doubling this concentration complete $(100 \%)$ inhibition was observed.

\section{(iii) 10th day observation}

On the $10^{\text {th }}$ day of PI with $5 \mu \mathrm{g} / \mathrm{ml}$ the Leptospira were showing a reduction in their growth potentiality up to $73 \%$. Interestingly when the concentration was doubled a very good inhibition of up to $87 \%$ was observed. No live Leptospira (100\% inhibition) was observed on this $10^{\text {th }}$ day for the concentration of $40 \mu \mathrm{g} / \mathrm{ml}$ and above. Based on the data obtained from this study, the PAE were found to be effective inhibitor of Leptospira interrogans autumnalis (Figure: 1).

\section{MIC of EAE}

Similarly the effect of EAE on the Leptospira was tested with the same concentration as that of the PAE. On $1^{\text {st }}$ and $2^{\text {nd }}$ day of observation EAE exhibited least inhibition (19\% and 40\%) even at $620 \mu \mathrm{g} / \mathrm{ml}$ concentration.

\section{(i) $4^{\text {th }}$ day observation}

L. autumnalis growth was observed on the $4^{\text {th }}$ day after treatment with EAE extract dilutions of 5 $\mu \mathrm{g} / \mathrm{ml}, 10 \mu \mathrm{g} / \mathrm{ml}, 20 \mu \mathrm{g} / \mathrm{ml}, 40 \mu \mathrm{g} / \mathrm{ml}, 80 \mu \mathrm{g} / \mathrm{ml}$, $160 \mu \mathrm{g} / \mathrm{ml}, 320 \mu \mathrm{g} / \mathrm{ml}$ and $640 \mu \mathrm{g} / \mathrm{ml}$; the decline in growth was noticed to be approximately $13 \%$, $15 \%, 17 \%, 36 \%, 43 \%, 62 \%, 66 \%$ and $79 \%$ respectively, in comparison with that of the control on the same day.

\section{(ii) $6^{\text {th }}$ day observation}

Interesting results were observed only from the 40 $\mu \mathrm{g} / \mathrm{ml}$ concentration with $54 \%$ of reduction for the pathogen's growth inhibition potentiality. In the 5 $\mu \mathrm{g} / \mathrm{ml}$ concentration only $16 \%$ of inhibition was observed. A very minor difference was noted in the next concentration i.e., $10 \mu \mathrm{g} / \mathrm{ml}$ with a result of $23 \%$ decline in growth of the organisms was observed. In the next concentration $(20 \mu \mathrm{g} / \mathrm{ml})$ the reduction was $25 \%$ but in the next higher concentration $(160 \mu \mathrm{g} / \mathrm{ml})$ the inhibition was to a tune of $93 \%$. Interestingly in the next higher concentration $(320 \mu \mathrm{g} / \mathrm{ml}) 100 \%$ inhibition of the Leptospira was able to be observed.

\section{(iii) $8^{\text {th }}$ day observation}

On the $8^{\text {th }}$ day observation a gradual reduction in the growth potential was noted up to the $20 \mu \mathrm{g} / \mathrm{ml}$ concentration and a drastic drop in the growth was noted in the $40 \mu \mathrm{g} / \mathrm{ml}$ dilution. The lower concentrations were showing respectively growth reductions of $16 \%, 23 \%$ and $25 \%$ for the 5,10 and $20 \mu \mathrm{g} / \mathrm{ml}$ dilutions respectively. The sudden drop in the cell count at the $40 \mu \mathrm{g} / \mathrm{ml}$ was to a tune of $68 \%$ reduction. On an average $86 \%$ of inhibition was observed with $80 \mu \mathrm{g} / \mathrm{ml}$ treatment on this day of observation. Still the growth was dwindling to give a result of $98 \%$ in the next concentration of $160 \mu \mathrm{g} / \mathrm{ml}$. Beyond this concentration no live Leptospira (100\% inhibition) was observed.

MIC of EAE against $L$. autumnalis

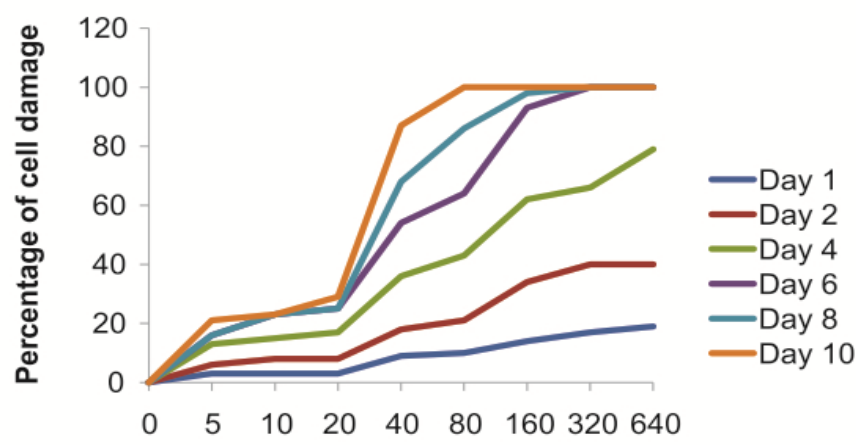

$\operatorname{EAE}(\mu \mathrm{g} / \mathrm{ml})$ 


\section{(iv) $10^{\text {th }}$ day observation}

For the $10^{\text {th }}$ day observation of PI only a marginal reduction of growth at low concentration (up to $20 \mu \mathrm{g} / \mathrm{ml}$ ) of the extract treatment and an excellent result from the $40 \mu \mathrm{g} / \mathrm{ml}$ were noted. The MIC results were $21 \%, 23 \%$ and $29 \%$ respectively for the extract concentrations of 5, 10 and $20 \mu \mathrm{g} / \mathrm{ml}$. A sudden drop in growth to a tune of $87 \%$ visibly was noted for the $40 \mu \mathrm{g} / \mathrm{ml}$ on the eighth day with this extract. Interestingly above than this concentration no Leptospira (100\% MIC) were able to be observed (Figure: 2).

\section{Discussion}

The phytochemical analysis of PAE and EAE revealed the presence various secondary metabolites like tannins, alkaloids, saponins, flavanoids, terpenes and anthraquinones in the aqueous extracts of the medicinal plants. Tube dilution technique (TDT) was followed in the present study to have a better understanding about the efficacy of drugs against Leptospira autumnalis by adding various concentrations $(5 \mu \mathrm{g} / \mathrm{ml}$ double fold concentration of up to 640 $\mu \mathrm{g} / \mathrm{ml}$ ) of the compound in the EMJH liquid medium. Darkfield microscope was utilized and the results were impregnated as percentages. Utility of darkfield microscope for the TDT was recommended for Leptospira by some early researchers (Ben- yaacov, et al., 1994).

Studies are available on many Indian medicinal plants such as Ocimum sanctum, Herpestis monneria, Azardirachtha indica, Curcuma longa, Aegle marmelos and Nelumbo nucifera that exhibited maximum inhibition against Escherichia coli, Klebsiella pneumonia, Staphylococcus aureus and Vibrio cholera (Dahanukar et al., 2000). However, anti-bacterial effects of plants such as P. amarus and E. alba are poorly studied. Moreover, such studies on Leptospira are still scanty. Thus in the present study anti-leptospiral activity of P. amarus and E. alba was carried out and the interesting MIC data obtained during the study are discussed below:
PAE of known quantities were dissolved in sterile phosphate buffered saline (PBS) $7.2 \mathrm{pH}$ and used for the study. A negative control of plain sterile saline was used simultaneously along with the test vials. Starting from $5 \mu \mathrm{g} / \mathrm{ml}$ double fold concentration up to $640 \mu \mathrm{g} / \mathrm{ml}$ were prepared and treated with approximately $2 \times 10^{4} / \mathrm{ml}$ of Leptospira. When the results were observed on $4^{\text {th }}$ day from the $40 \mu \mathrm{g} / \mathrm{ml}$ concentration with $54 \%$ of reduction for the pathogen's growth inhibition potentiality. Up to $20 \mu \mathrm{g} / \mathrm{ml}$ concentration the PAE was giving up to $39 \%$ of anti-leptospiral inhibition only. In the $80 \mu \mathrm{g} / \mathrm{ml}$ concentration the reduction was $54 \%$ but in the next higher concentration $(160 \mu \mathrm{g} / \mathrm{ml}) \quad$ the inhibition was to a tune of $61 \%$. Interestingly in the next higher concentration $(320 \mu \mathrm{g} / \mathrm{ml}$ and $640 \mu \mathrm{g} / \mathrm{ml}) 71 \%$ and $85 \%$ inhibition of the Leptospira was able to be observed.

During the $6^{\mathrm{h}}$ day of the PI approximately $43 \%$ of decline in growth was noted. Interestingly in 80 $\mu \mathrm{g} / \mathrm{ml}$ around $96 \%$ of reduction was noted. From the next concentration of $160 \mu \mathrm{g} / \mathrm{ml}$, no live Leptospira (100\% inhibition) was observed. However, on the $8^{\text {th }}$ day observation approximately $58 \%$ of growth reduction was noted at the $5 \mu \mathrm{g} / \mathrm{ml}$ but in $10 \mu \mathrm{g} / \mathrm{ml}$ a gradual increase in inhibition of $70 \%$ was noted. But with the 80 $\mu \mathrm{g} / \mathrm{ml}$ a reduction of $99 \%$ was noted. Beyond this concentration $100 \%$ inhibition was observed. Interestingly on the $10^{\text {th }}$ day just for $20 \mu \mathrm{g} / \mathrm{ml} \mathrm{a}$ very good inhibition of up to $87 \%$ was observed. $100 \%$ inhibition was observed on this day observation for the concentration of $40 \mu \mathrm{g} / \mathrm{ml}$ and above. Thus the aqueous extract had a good MIC over the Leptospira tested. In some earlier studies pertaining to MIC, investigations were made on the anti-microbial activity of $\mathrm{P}$. amarus tested against various bacteria including human intestinal facultative anaerobic flora. The aqueous extract of $\mathrm{P}$. amarus controlled the growth of $\mathrm{P}$. aeruginosa, S. aureus, E. fecalis, E. coli, P. mirablis and K. Pneumonia at $50 \mathrm{mg} / \mathrm{ml}$ (Babatunde et al., 2014). However, in the present study antimicrobial activity of PAE was tested 
against Leptospira autumnalis and the extract showed greater inhibitory activity (100\%) in 80 $\mu \mathrm{g} / \mathrm{ml}$ concentration of the extract.

Several workers use different solvents systems for the extraction of bioactive compounds like Tannins, alkaloids, flavonoids, flavonones, terpenoids, saponins, lignans, sterols, anthraquinones, etc from medicinal plants. Okolo and his coworkers analyzed the efficacy of various solvents such as aqueous, chloroform and ethanol in extracting the bioactive compound from Phyllanthus amarus. Their study clearly revealed that only aqueous extraction showed the presence of highest number of bioactive compounds like alkaloids, anthraquinone, balsam, flavonoids, saponins, steroids, tannins and terpenoids than chloroform and ethanol (Okolo et al., 2012). They also compared the presence of these bioactive compounds from various parts of the plant such as leaves, stem, seeds and roots. Leaves showed the highest number of bioactive compounds. The current study goes in full agreement with the above findings in utilizing aqueous as a solvent system for the extraction of bioactive compounds and leaves were chosen. The extracts of both the plant P. amarus and E. alba exhibited antileptospiral activity.

In another study four types of solvents namely aqueous, benzene, ethanol and methanol were used for the extraction of bioactive compound from A. vasica. Aqueous and methanol extracts were able to inhibit the motility of Leptospira interrogans at a concentration of 10 to 1000 $\mathrm{mg} / \mathrm{ml}$. The ethanol extract extracts of A. vasica was able to control leptospiral activity in all the concentrations tested ranging from 0.1 to 1000 $\mathrm{mg} / \mathrm{ml}$. In the same study the plant extract treated L. interrogans did not show the presence of inclusion body (surface vacuole) on the outer envelope of the fresh isolate. Inclusion body in L. interrogans is normally associated with the virulence of this pathogen (Nelson, et al., 2013). In contrast to the above finding in the present study a much lesser concentration of $160 \mu \mathrm{g} / \mathrm{ml}$ (PAE) and $320 \mu \mathrm{g} / \mathrm{ml}$ (EAE) 100\% inhibition in leptospiral growth was observed which is encouraging in the management of this disease. Four crude and five purified xanthones namely alpha-mangostin, gamma-mangostin, garcinone $\mathrm{C}$, garcinone D and 8-deoxygartanin of Garcinia mangostana were active against the L. interrogans serovars such as bataviae, autumnalis, javanica and saigon and L. biflexa serovar patoc. All four crude extracts had greater MICs ranging from 200 to $\geq 800 \mu \mathrm{g} / \mathrm{ml}$. The anti-leptospiral activity of five purified xanthones was variable in the range of 100 to $\geq 200 \mu \mathrm{g} / \mathrm{ml}$ (Seesom, et al., 2013). The above finding is in agreement with the present study that for PAE 20 to $\geq 160 \mu \mathrm{g} / \mathrm{ml}$ is giving 50 to $100 \%$ inhibition respectively.

EAE was tested against Leptospira with the same concentration as that of the PAE. The interesting results obtained are discussed below: L. autumnalis growth was observed on the $4^{\text {th }}$ day after treatment with EAE extract dilutions of 5 $\mu \mathrm{g} / \mathrm{ml}, 10 \mu \mathrm{g} / \mathrm{ml}, 20 \mu \mathrm{g} / \mathrm{ml}, 40 \mu \mathrm{g} / \mathrm{ml}, 80 \mu \mathrm{g} / \mathrm{ml}$, $160 \mu \mathrm{g} / \mathrm{ml}, 320 \mu \mathrm{g} / \mathrm{ml}$ and $640 \mu \mathrm{g} / \mathrm{ml}$; the decline in growth was noticed to be approximately $13 \%$, $15 \%, 17 \%, 36 \%, 43 \%, 62 \%, 66 \%$ and $79 \%$ respectively, in comparison with that of the control on the same day. During the $6^{\text {th }}$ day observation at $40 \mu \mathrm{g} / \mathrm{ml}$ concentration around $54 \%$ of reduction for the bacteria was observed but in the concentration of $160 \mu \mathrm{g} / \mathrm{ml}$ the inhibition was to a tune of $93 \%$. Interestingly in the next concentrations $\geq 320 \mu \mathrm{g} / \mathrm{ml} \mathrm{100 \%} \mathrm{MIC} \mathrm{of}$ the Leptospira was able to be observed. On the $8^{\text {th }}$ day observation a gradual reduction in the growth was noted up to the $20 \mu \mathrm{g} / \mathrm{ml}$ concentration but in the $40 \mu \mathrm{g} / \mathrm{ml}$ dilution a drastic drop (68\%) in the growth was noted. On an average $86 \%$ of inhibition was observed with $80 \mu \mathrm{g} / \mathrm{ml}$ treatment for the $8^{\text {th }}$ day observation. Still the growth was dwindling to give a result of $98 \%$ in the next concentration of $160 \mu \mathrm{g} / \mathrm{ml}$. Beyond this concentration no live Leptospira (100\% inhibition) was observed. For the $10^{\text {th }}$ day observation of PI only a marginal reduction of growth at low concentration (up to $20 \mu \mathrm{g} / \mathrm{ml}$ ) of the extract treatment and an excellent result from 
$40 \mu \mathrm{g} / \mathrm{ml}$ were noted. A sudden drop in growth to a tune of $87 \%$ visibly was noted for the $40 \mu \mathrm{g} / \mathrm{ml}$ on the eighth day with this extract. Interestingly above than this concentration no Leptospira (100\% inhibition) were able to be observed. In an earlier study on Eclipta alba, bioactive compounds were extracted using various solvents like acetone, ethanol, petroleum ether and water. Extracted compound was diluted by using double distilled water. Various concentrations of those compounds were made ranging from 50, 100, 150, 200 and $250 \mu \mathrm{g}$ in $1 \mathrm{ml}$ and were used for antileptospiral activity. Aqueous extracts were found to be superior to all other solvent extracts. At the lowest concentration level of $50 \mu \mathrm{g} / \mathrm{ml}$ MIC was observed for aqueous extracts (80\% inhibition), where as the next better solvent was found to be acetone to get an MIC at $100 \mu \mathrm{g} / \mathrm{ml}$ against $\mathrm{L}$. australis, L. autumnalis, L. grippptyphosa and L. icterohaemorrhagiae than other solvents utilized in their study (Prabhu, et al., 2008).

The above study is very much encouraging and going hand in hand with the results of the present study in getting excellent result with aqueous extracts (PAE and EAE) against the pathogen. In a previous study the efficacy of Eclipta alba against L. interrogans serogroups was investigated by evaluating the MIC of the extracts using solvents such as acetone, water and saponified lipid. They compared standard tube dilution with micro dilution technique. Tube dilution technique was reported to be a better tool in the evaluation of MIC by the authors (Mathew, 2001). In the present study tube dilution technique for leptospiral MIC was giving convincing result. This technique could increase the pathogen's survival rate and the results of growth inhibition could be because of the active principle of medicinal plants and not because of any stress or other abiotic and biotic factors.

\section{Conclusion}

Multidrug resistance, antibiotic sensitivity and allergic complications including many side effects have made Indian medicine especially from herbal sources as a very important infectious diseases management tool. Though P. amarus and E. alba have also proven to be important among medicinal plants with anti-microbial, anti-oxidant, hepatorenal protective activities. The present study revealed the presence of tannins, alkaloids, saponins, flavonoids, terpenes and anthraquinones in the leaves of these plants extracts thereby exhibiting anti-leptospiral activity. By observing the drug dose concentration the extracts of $\mathrm{P}$. amarus was found to be having a better active principle $(160 \mu \mathrm{g} / \mathrm{ml})$ than the extracts of E. alba $(320 \mu \mathrm{g} / \mathrm{ml})$. Thus the study has given hope of possible Indian medicinal treatment for the human leptospirosis with these Indian medicinal plants.

\section{References}

1. Isa SE, Onyedibe KI, Okolo MO, Abiba, AE, Mafuka JS, et al., (2014). "A 21Year-old student with fever and profound jaundice". PLoS Negl Trop Dis. 2014; 8: e2534.

2. Parasuraman B, Pichai K, and Karumana GK. "Study on the Prevalence of Leptospirosis among fever cases reported from private clinics in the urban areas of Villupuram District, Tamil Nadu, India”. Osong Pub. Health Res. Perspectives. 2014; 5: 54-67.

3. Calvo-Cano A, Aldasoro E, Ramírez MF, et al "Two cases of laboratory-confirmed leptospirosis in travellers returning to Spain from Thailand, September 2013". Euro Surveill. 2014; 19: 1-3.

4. Kumar SG, Adithan C, Harish BN, Sujatha S, Gautam R and Malini A. (2013). "Antimicrobial resistance in India: A review". J Nat Sci Bio Med. 2013; 4: 286-91.

5. Chakraborty A, Satoshi M, Sharon YAM, et al. "In-vitro sensitivity and resistance of 46 Leptospira strains isolated from rats in the Philippines to 14 antimicrobial agents. Antimicrob Agents Chemother. 2010; 54: 5403-05. 
6. Maity T, Pahari N, Bera $\mathrm{K}$ and Chakraborty M. "Recent development in herbal drug research for global health care. World J Pharmceutical Res. 2013; 2: 83854.

7. Sadiaque J, Rqobab NA, Bughaith MF and Gindey AR. "The bioactivity of certain medicinal plants on the stabilization of RBC membrane system". Fitoterapia. 1989; 1: 525-32.

8. Parekh J, Nair $\mathrm{R}$ and Chanda $\mathrm{S}$. "Preliminary screening of some folklore medicinal plants from western India for potential antimicrobial activity". Indian $\mathbf{J}$ Pharmacol. 2005; 37: 408-09.

9. Evans WC. "Textbook of Pharmacognosy". $13^{\text {th }}$ ed., Cambridge University Press, London.1989.

10. Sofowora A. "Medicinal plants and Traditional medicine in Africa". Spectrum Books Ltd., Ibadan, Nigeria.1993.

11. Oie S, Hironaga K, Koshiro A, Konishi H and Yoshii Z. "In-vitro susceptibilities of five leptospira strains to 16 antimicrobial agents". Antimicrobl Agents and Chemother. 1983; 24: 905-08.

12. Mathew LM. "Comparative analysis of Acetone, Water and Saponified extracts of Phyllanthus niruri against Leptospirainterrogans sero groups in- vitro (Dissertation)". Periyar University, Salem, Tamilnadu, India.

13. Ben-yaacov R, Knoller S and Pierard GM. "Drug resistance capability of the pathogenic microbes in-vitro". Antimicrob Agents Chemother. 1994; 38: 422-26.

14. Dahanukar SA, Kulkarni RA, Rege RE. "Pharmacology of medicinal plants and natural products. Indian Jour of Pharmacol. 2000; 32: 81-118.

15. Babatunde SK, Abubakare AA, Abdulraheem, YJ and Ajiboye, EA. "Antimicrobial activity of Phyllanthus amarus on some human intestinal facultatively anaerobic flora. Internl. J. Med. Biomed. Res. 2014; 3: 52-7.

16. Okolo SC, Okoh-Esene RU, Ikokoh PP, Olajide $\mathrm{OO}$ and Anjorin ST. "Phytochemicals, mineral content and antimicrobial screening of Phyllanthus amarus in Abuja, Nigeria”. J Microbiol Biotech Res. 2012; 2: 17-22.

17. Nelson J, Chairman K, RanjitSingh AJA, Padmalatha $\mathrm{C}$ and Hepsibah B. "Cytomorphological Changes and Inhibition of Inclusion Body Formation in Leptospira interrogans on Treatment with the Extracts of Adhatoda vasica". Adv Tech Biol Med. 2013; 1: 1-4.

18. Seesom W, Jaratrungtawee A, Suksamrarn S, Mekseepralard C, et al.,. "Antileptospiral activity of xanthones from Garcinia mangostana and synergy of gamma-mangostin with penicillin G". BMC Compl Altern Med. 2013; 13: 182.

19. Prabhu N, Innocent JP, Chinnaswamy P, Natarajaseenivasan K and Sarayu L. "Invitro evaluation of Eclipta alba against serogroups of Leptospira interrogans". Indian J Pharma Sci. 2008; 70: 788-91. 